\title{
Mobility of flumioxazin herbicide in a Dystrophic Red Yellow Latosol at Brazilian Southern Amazon
}

\author{
Oscar Mitsuo Yamashita ${ }^{1^{*}}$, Rafael Cesar Tieppo ${ }^{2}$, Ricardo Vicentin Carvalho ${ }^{3}$, Marco Antonio Camillo de \\ Carvalho $^{1,2}$, Rivanildo Dallacort ${ }^{1,2}$, Walmor Moya Peres ${ }^{3}$, Grace Queiroz David ${ }^{3}$, Hudson de Oliveira \\ Rabelo $^{3}$, Adriano Maltezo da Rocha ${ }^{3}$, Lara Caroline Alves de Oliveira ${ }^{3}$
}

\author{
${ }^{1}$ Postgraduate Program in Amazonian Biodiversity and Agroecosystems. Mato Grosso State University, Alta Floresta, \\ MT, Brazil \\ ${ }^{2}$ Postgraduate Program in Environments and Production Systems. Mato Grosso State University, Tangará da Serra, \\ MT, Brazil \\ ${ }^{3}$ Faculty of Biological and Agrarian Sciences. Mato Grosso State University, Alta Floresta, MT, Brazil
}

*Corresponding autor: yama@unemat.br

Abstract

Herbicides are chemicals which can contaminate soil and water, if inadvertently used. In the soil, the herbicide may undergo adsorption and leaching or degradation by physical, chemical and biological processes in addition to being absorbed by the weeds and / or cultivation. The aim of this study was to determine the mobility of flumioxazin in Dystrophic Red Yellow Latosol, in the southern Amazon, using sorghum plant as test under different rainfall indexes. We used PVC pipes, which were filled with soil. The experimental design was completely randomized in a $2 \times 2 \times 5$ factorial scheme, consisting of herbicide treatments [with or without flumioxazin ( $\left.50 \mathrm{~g}_{\text {i.a. ha }}{ }^{-1}\right)$ ], rain $(40$ or $80 \mathrm{~mm}$ ) and soil depths $(2.5,5,10,15$ and $30 \mathrm{~cm}$ ). After each rainfall simulation, the tubes were removed and sorghum seeds were placed in the depths 2.5, 5, 10, 15 and $30 \mathrm{~cm}$ from the top of the columns. It was observed a higher activity of flumioxazin in the initial $2.5 \mathrm{~cm}$. In all depths where herbicide effect was observed, it was also observed the interruption of sorghum growth, being more intense in the simulations of $80 \mathrm{~mm}$ of rainfall. The herbicide presented high adsorptive capacity in Dystrophic Red Yellow Latosol, with mobility up to the first $2.5 \mathrm{~cm}$ along the profile.

Keywords: leaching, herbicide, contamination, sorghum bioassay.

Abbreviations: PVC pipe_polyvinyl chloride pipe.

Introduction

In order to decrease weed population and to improve the efficiency of production, herbicides have been used in agricultural production. However, the indiscriminate use of this product has contributed to the increase of contamination of soil, water and ultimately on animal and human life as well (Nicholls, 1988; López-Piñeiro, 2013).

Once herbicides penetrate into the soil, they can interact by adsorption, leaching, degradation or absorption by means of physical, chemical and biological processes with cultivated plants and weeds. Thus, knowledge about these factors is valuable in order to predict herbicide interactions in the environment and subsequent crops (Troiano et al., 2001; Carbonari et al., 2010).

Currently, agricultural systems are dependent on the use of agrochemicals, that can provide leaching of molecules and water contamination. Thus, it should be analyzed by professionals and agencies of control (Rozemeijer \& Broers, 2007; Alister et al., 2008).

Herbicide leaching becomes a problem when water enters the system through rainfall or irrigation. When water contacts soil and plants, it dissolves and transport part of these chemical substances, through soil pores, until finally reaches soil saturated zone. This negatively affects the quality of subsurface reservation water (Mitchell et al., 2005; Papiernik et al., 2012).

However, leaching is a critical factor for herbicides application, since the process is necessary for superficial incorporation of most part of these products applied directly in the soil. Leaching process allows the products achieving seeds or plants in their early development. Usually, leaching is greater in sandy soil than clayey and silty soils (Fast et al., 2010).

The behavior of herbicides depends on climatic factors and soil properties. There are mainly three processes that can occur with herbicides in the soil, namely retention, processing and transportation (Silva et al. 2007; Mueller et al., 2014).

Flumioxazin presents low solubility in water $\left(1.79 \mathrm{mg} \mathrm{L}^{-1}\right.$ at $25^{\circ} \mathrm{C}$ ) and low vapor pressure (Rodrigues \& Almeida, 2011), suggesting it has low potential for volatilization. Its activity depends on environmental factors, such as light and temperature, but the process is decreased when exposed to dry soil (Ferrel et al., 2005; PPDB, 2017). 
As this herbicide is used in pre-emergence, it is essential to know its activity in the soil, knowledge of sorption processes, as well as leaching of herbicides, allows the recommendation of different herbicide rates according to soil type and, consequently. , more efficient weed control (Deuber et al., 2009; Alister et al., 2008; Umiljendić et al., 2013; Yamashita et al., 2018).

Incorrect and indiscriminate use of herbicides in crops is known to have caused several environmental problems, such as contamination of soil and surface and groundwater (Tanabe et al., 2001; Prado et al., 2013; Pereira et al., 2017). This is due to the poor information on the dynamics of herbicides applied in different biomes, with soils with specific characteristics that result in a single recommendation for different cultivation conditions, generating short and long term problems that are often difficult to reverse. Adsorption and bleaching studies demonstrate that organic matter content in different soil types influences flumioxazine adsorption, suggesting that this herbicide rate may be recommended according to soil adsorption capacity (Carbonari et al., 2010; Yamashita et al., 2018). In addition, there has been little published information on flumioxazin behavior in tropical soils and even more so when it comes to the use of this herbicide under cultivation conditions in the Amazon biome. Thus, there is a lack of information for these specific conditions, both soil and climate and rainfall. From the knowledge of the behavior of this herbicide in this condition, it will be possible to make safe recommendations from both the technical and environmental point of view, this work was done.

Thus, for the related conditions, this work aimed to evaluate the mobility of flumioxazine under different conditions of simulated water regime in a Dystrophic Red Yellow Latosol.

Results

\section{Data analysis}

Data analysis showed significance for dry matter and plant height with triple interaction among factors (herbicide, rainfall, depth). About phytotoxicity, there was significance for herbicide and depth, and interactions between herbicide versus depth and rainfall versus depth (Table 2 ).

\section{Herbicide and rainfall simulations}

After rainfall simulations of 40 and $80 \mathrm{~mm}$, the flumioxazin herbicide was found up to 0.10 and $0.30 \mathrm{~m}$ respectively. It caused a dry matter decrease in sorghum crop. Therefore, the flumioxazin has capability to leach through the studied layers of soil and provided phytotoxicity up to $0,30 \mathrm{~m}$ that negatively impacted sorghum's dry matter (Table 3 ).

These results suggest that leaching of flumioxazin depends on the amount of water in the soil. Similar results showed leaching of flumioxazin up to $5 \mathrm{~cm}$ in a ultisol and up to 10 $\mathrm{cm}$ in an Dystrophic Red Yellow Latosol, with simulated rainfall of 45 and $90 \mathrm{~mm}$ (Oliveira et al., 1999). However, Deuber et al. (2009), found flumioxazin leaching only at depths 2.75 and $2.20 \mathrm{~cm}$, for $50 \mathrm{~mm}$ rainfall simulation, in a Eutrophic Red Latosol and in a Dystrophic Red Yellow Latosol, respectively. These differences possibly occurred due to the composition of clays and to the presence of organic matter in the different soil types. When simulating a $40 \mathrm{~mm}$ rainfall amount on a Dystrophic Red Yellow Latosol at more superficial layer $(2.5 \mathrm{~cm})$, it was found lower dry matter amount per plant, regardless of herbicide treatments (Table 4). Regarding the rainfall of $80 \mathrm{~mm}$, for soil with and without herbicide presence, it was possible to note that biomass production was similar through all the sowing depths (Table 5). When the rainfall simulation was of 40 $\mathrm{mm}$, it was found that the herbicide caused phytotoxic effects in sorghum plants up to $10 \mathrm{~cm}$ of soil depth. From this depth, the biomass values reached were at least $21 \%$ higher than lower depths, allowing inferences about the reduced mobility of flumioxazin in the soil under these conditions. When simulating a $50 \mathrm{~mm}$ rainfall, Deuber et al. (2009) observed reduced herbicide mobility and phytotoxicity on cucumber at just $1.50 \mathrm{~cm}$ deep. The low leaching of the herbicide, regardless of soil moisture, due to its low solubility in water has been reported, indicating that the recommendation of applying the herbicide should be directed according to the adsorptive capacity of each soil (Mueller et al., 2014; Lima et al., 1999).

\section{Herbicide and soil depth}

Even in presence of the herbicide, regardless of soil depth, there was no difference in biomass production for a simulation of $80 \mathrm{~mm}$ of rainfall. In this condition, the rainfall simulation provided dilution of the flumioxazin through the soil column. Similar results were observed by Oliveira et al. (1999), indicating that lower adsorption of the herbicide due to soil adsorptive sites occupied with water, can contribute positively to go down of the product.Height of sorghum plants were significantly affected by the residual effect of the herbicide. For simulation of $40 \mathrm{~mm}$ of rainfall, there was a reduction in height of sorghum plants only in the smaller depth, that is, at $2.5 \mathrm{~cm}$ depth, sorghum plants were very effectively affected by the action of the herbicide (Table 6). For simulation of $80 \mathrm{~mm}$ of rainfall, flumioxazin mobility was increased, and up to $10 \mathrm{~cm}$ of soil depth, the height of plants was lower than those in uncontaminated soil. The low mobility of the herbicide, limited to 2.5 and $10.0 \mathrm{~cm}$ of soil depth for rainfall of 40 and $80 \mathrm{~mm}$, respectively, indicates that flumioxazin has low solubility in water, does not dissociate, presenting low mobility along the soil profile (WSSA, 2002; Carbonari et al., 2010). Analyzing herbicide and depth interaction, in soil contaminated with flumioxazin for simulation of $40 \mathrm{~mm}$ of rainfall, the height of plants was affected only up to $2.5 \mathrm{~cm}$ of soil depth, providing a $43.0 \%$ reduction when compared to a $80 \mathrm{~mm}$ rainfall simulation. This indicates that lower rainfall can reduce herbicide mobility throughout the soil profile, harming the plants which are sown at lower soil depths (Table 7). In the absence of herbicide, simulation of $80 \mathrm{~mm}$ of rainfall was more suitable for initial growth of sorghum plants than half of this volume. At all soil depths, height of plants was negatively affected by the lower volume of supplied water. This result is due to the fact that these plants are more susceptible to hydric stress under these conditions. Without herbicide application, there was no difference in height of sorghum plants through the soil depths studied for both rainfall simulated amounts (Table 8). However, with flumioxazin application, simulation of $40 \mathrm{~mm}$ of rainfall provided more stratification and mobility throughout of substrate profile than simulation of $80 \mathrm{~mm}$ of rainfall. Rainfall of $40 \mathrm{~mm}$ provided smaller plants height at the lowest depth, this difference was significant regarding 5 and $10 \mathrm{~cm}$ depth. The highest plants were obtained in depths greater than $15 \mathrm{~cm}$. 
Table 1. Chemical, Physical, and Mineral Analysis of the Dystrophic Red Yellow Latosol used as substrate.

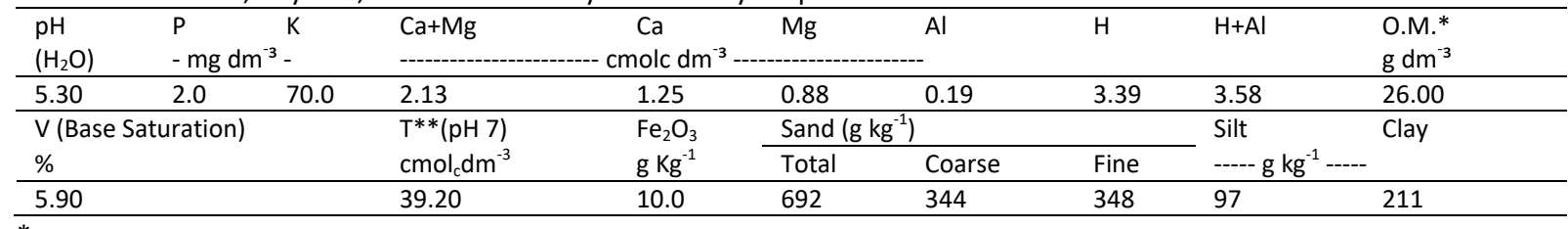

*O.M.: organic matter; ${ }^{* *} \mathrm{~T}$ : cation exchange capacity.

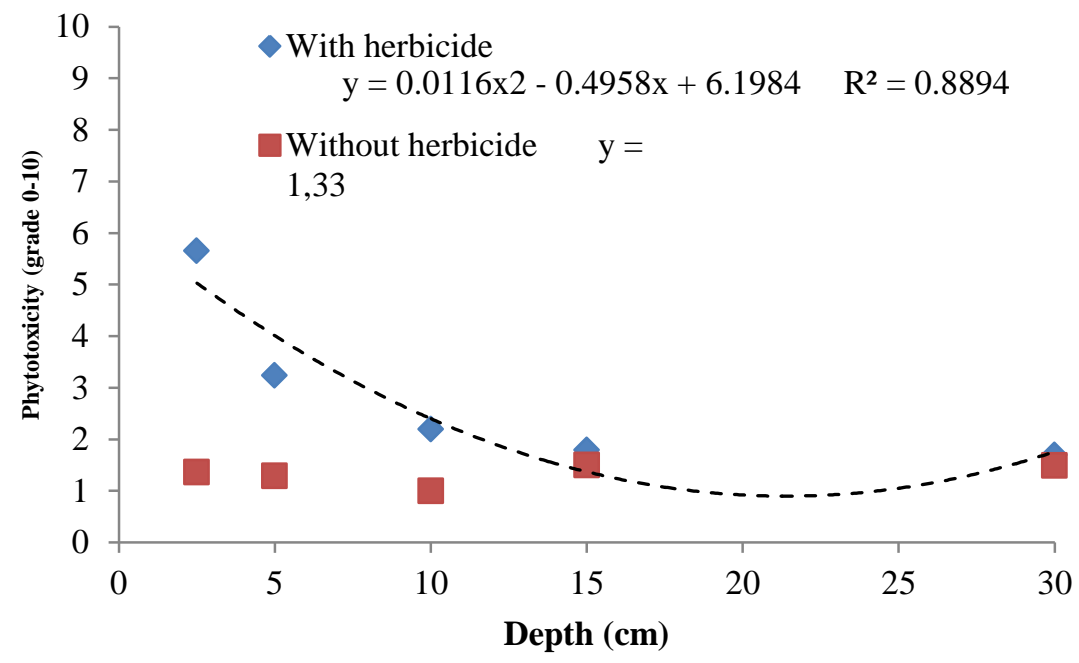

Fig 1. Phytotoxicity grade of sorghum by depth for flumioxazin herbicide presence.

Table 2. Statistical analysis for dry matter, plant height and phytotoxicity of sorghum cultivated in a Dystrophic Red Yellow Latosol

\begin{tabular}{|c|c|c|c|}
\hline \multirow{2}{*}{ Variation source } & Dry matter & Plant height & \multirow[t]{2}{*}{ Phytotoxicity } \\
\hline & 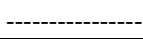 & - & \\
\hline Herbicide $(\mathrm{H})$ & $0.0000 * *$ & $73.829 * *$ & $50.212^{* *}$ \\
\hline Rainfall (C) & $0.0000 * *$ & $68.582^{* *}$ & $0.149 n s$ \\
\hline Depth (P) & $0.0000 * *$ & $14.687^{* *}$ & $10.886 * *$ \\
\hline $\mathrm{H}^{*} \mathrm{C}$ & $0.0002 * *$ & $15.390^{* *}$ & $0.239 \mathrm{~ns}$ \\
\hline$H^{* P}$ & $0.0000^{* *}$ & $12.461^{* *}$ & $11.171^{* *}$ \\
\hline$C * P$ & $0.0001 * *$ & $10.313^{* *}$ & $0.0682^{*}$ \\
\hline $\mathrm{H}^{*} \mathrm{C} * \mathrm{P}$ & $0.0037^{*}$ & $4.922^{*}$ & $0.331 \mathrm{~ns}$ \\
\hline Residue & 0.000014 & 0.950 & 0.216 \\
\hline C.V. (\%) & 9.95 & 5.28 & 21.92 \\
\hline
\end{tabular}

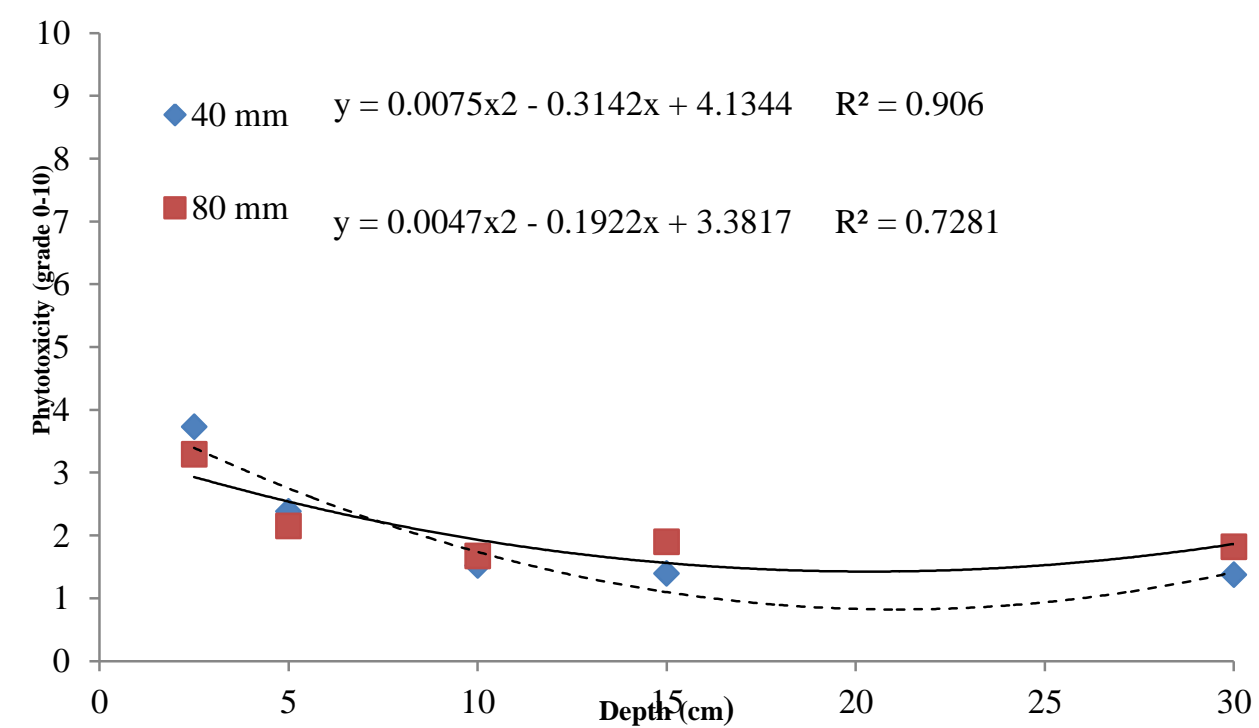

Fig 2. Phytotoxicity grade of sorghum by depth for rainfall simulation ( 40 and $80 \mathrm{~mm}$ ). 
Table 3. Unfolding of plant dry matter values of sorghum plants for the interaction between the factors "rain simulation", "depth" and "herbicide presence". The values shown in the table refer to the plant dry matter of sorghum plants (in grams).

\begin{tabular}{llll}
\hline \multirow{2}{*}{ Rainfall $(\mathrm{mm})$} & Depth $(\mathrm{cm})$ & Werbicide & Without \\
\cline { 3 - 4 } & 2.5 & $18.1 \mathrm{~b}$ & $33.3 \mathrm{a}$ \\
& 5.0 & $26.9 \mathrm{~b}$ & $47.5 \mathrm{a}$ \\
& 10.0 & $30.4 \mathrm{~b}$ & $43.3 \mathrm{a}$ \\
& 15.0 & $35.0 \mathrm{a}$ & $38.7 \mathrm{a}$ \\
& 30.0 & $40.0 \mathrm{a}$ & $40.4 \mathrm{a}$ \\
\hline & 2.5 & $32.1 \mathrm{~b}$ & $45.0 \mathrm{a}$ \\
& 5.0 & $27.2 \mathrm{~b}$ & $50.0 \mathrm{a}$ \\
& 10.0 & $30.3 \mathrm{~b}$ & $46.6 \mathrm{a}$ \\
& 15.0 & $34.1 \mathrm{~b}$ & $43.3 \mathrm{a}$ \\
\hline C.V. (\%) & 30.0 & $34.2 \mathrm{~b}$ & $50.0 \mathrm{a}$ \\
\hline
\end{tabular}

Mean followed by the same letter on the line, do not differ by Tukey test at $5 \%$ probability.

Table 4. Unfolding of plant dry matter values of sorghum plants for the interaction between the factors "herbicide presence", "depth" and "rain simulation". The values shown in the table refer to the plant dry matter of sorghum plants (in grams).

\begin{tabular}{llll}
\hline \multirow{2}{*}{ Herbicide } & Depth $(\mathrm{cm})$ & 40 & Rainfall $(\mathrm{mm})$ \\
\cline { 3 - 4 } & 2.5 & $18.1 \mathrm{~b}$ & 30 \\
\multirow{3}{*}{ With } & 5.0 & $26.9 \mathrm{a}$ & $27.2 \mathrm{a}$ \\
& 10.0 & $30.3 \mathrm{a}$ & $30.4 \mathrm{a}$ \\
& 15.0 & $38.7 \mathrm{a}$ & $34.1 \mathrm{a}$ \\
& 30.0 & $40.4 \mathrm{a}$ & $34.2 \mathrm{a}$ \\
\hline \multirow{2}{*}{ Without } & 2.5 & $33.3 \mathrm{~b}$ & $45.0 \mathrm{a}$ \\
& 5.0 & $47.5 \mathrm{a}$ & $50.0 \mathrm{a}$ \\
& 10.0 & $43.3 \mathrm{a}$ & $46.6 \mathrm{a}$ \\
\hline C.V. (\%) & 15.0 & $35.0 \mathrm{~b}$ & $43.3 \mathrm{a}$ \\
\hline Mean followed by the same letter on the line, do not differ by Tukey test at 5\% probability & & $50.0 \mathrm{a}$ \\
\hline
\end{tabular}

Mean followed by the same letter on the line, do not differ by Tukey test at $5 \%$ probability.

Table 5. Unfolding of plant dry matter values of sorghum plants for the interaction between the factors "herbicide presence", "rain simulation" and "depth". The values shown in the table refer to the plant dry matter of sorghum plants (in grams).

\begin{tabular}{lllllll}
\multirow{2}{*}{ Herbicide } & Rainfall & \multicolumn{5}{c}{ Depth $(\mathrm{cm})$} \\
\cline { 2 - 6 } & $(\mathrm{mm})$ & 2.5 & 5.0 & 10.0 & 15.0 & 30.0 \\
\hline \multirow{2}{*}{ With } & 40 & $18.1 \mathrm{c}$ & $26.9 \mathrm{~b}$ & $30.4 \mathrm{~b}$ & $38.7 \mathrm{a}$ & $40.4 \mathrm{a}$ \\
& 80 & $32.1 \mathrm{a}$ & $27.2 \mathrm{a}$ & $30.3 \mathrm{a}$ & $34.1 \mathrm{a}$ & $34.2 \mathrm{a}$ \\
\hline \multirow{2}{*}{ Without } & 40 & $33.3 \mathrm{c}$ & $47.5 \mathrm{a}$ & $43.3 \mathrm{ab}$ & $35.0 \mathrm{c}$ & $40.0 \mathrm{bc}$ \\
& 80 & $45.0 \mathrm{a}$ & $50.0 \mathrm{a}$ & $46.6 \mathrm{a}$ & $43.3 \mathrm{a}$ & $50.0 \mathrm{a}$ \\
\hline C.V. (\%) & 9.95 & & & & \\
\hline
\end{tabular}

Mean followed by the same letter on the line do not differ by Tukey test at $5 \%$ probability.

Table 6. Unfolding height values of sorghum plants for the interaction between factors "rain simulation", "depth" and "herbicide presence". The values shown in the table refer to the height of sorghum plants (in $\mathrm{cm}$ ).

\begin{tabular}{llll}
\hline \multirow{2}{*}{ Rainfall $(\mathrm{mm})$} & \multirow{2}{*}{ Depth $(\mathrm{cm})$} & \multicolumn{2}{c}{ Herbicide } \\
\cline { 3 - 4 } & 2.5 & $12.33 \mathrm{~b}$ & Without \\
\hline \multirow{3}{*}{40} & 5.0 & $16.07 \mathrm{a}$ & $17.63 \mathrm{a}$ \\
& 10.0 & $17.55 \mathrm{a}$ & $17.17 \mathrm{a}$ \\
& 15.0 & $19.64 \mathrm{a}$ & $18.67 \mathrm{a}$ \\
& 30.0 & $19.49 \mathrm{a}$ & $18.24 \mathrm{a}$ \\
& 2.5 & $17.72 \mathrm{~b}$ & $18.60 \mathrm{a}$ \\
\hline & 5.0 & $16.64 \mathrm{~b}$ & $21.20 \mathrm{a}$ \\
& 10.0 & $17.98 \mathrm{~b}$ & $21.20 \mathrm{a}$ \\
& 15.0 & $19.21 \mathrm{a}$ & $20.23 \mathrm{a}$ \\
\hline C.V. (\%) & 30.0 & $18.41 \mathrm{a}$ & $20.25 \mathrm{a}$ \\
\hline
\end{tabular}

Mean followed by the same letter on the line, do not differ by Tukey test at $5 \%$ probability. 
Table 7. Unfolding the height values of sorghum plants for the interaction between the factors "herbicide presence", "depth" and "rain simulation". The values shown in the table refer to the height of sorghum plants (in $\mathrm{cm}$ ).

\begin{tabular}{llll}
\hline \multirow{2}{*}{ Herbicide } & Depth $(\mathrm{cm})$ & \multicolumn{2}{l}{ Rainfall $(\mathrm{mm})$} \\
\cline { 3 - 4 } & 2.5 & 40 & 80 \\
\hline \multirow{3}{*}{ With } & 5.0 & $12.33 \mathrm{~b}$ & $17.72 \mathrm{a}$ \\
& 10.0 & $16.07 \mathrm{a}$ & $16.64 \mathrm{a}$ \\
& 15.0 & $17.55 \mathrm{a}$ & $17.98 \mathrm{a}$ \\
& 30.0 & $19.64 \mathrm{a}$ & $19.21 \mathrm{a}$ \\
\multirow{2}{*}{ Without } & 2.5 & $19.49 \mathrm{a}$ & $18.41 \mathrm{a}$ \\
& 5.0 & $17.63 \mathrm{~b}$ & $21.20 \mathrm{a}$ \\
& 10.0 & $17.17 \mathrm{~b}$ & $21.20 \mathrm{a}$ \\
& 15.0 & $18.67 \mathrm{~b}$ & $20.23 \mathrm{a}$ \\
\hline C.V. (\%) & 30.0 & $18.24 \mathrm{~b}$ & $20.25 \mathrm{a}$ \\
\hline
\end{tabular}

Mean followed by the same letter on the line, do not differ by Tukey test at $5 \%$ probability.

Table 8. Unfolding the height values of sorghum plants for the interaction between the factors "rain simulation", "depth" and "herbicide presence". The values shown in the table refer to the height of sorghum plants (in $\mathrm{cm}$ ).

\begin{tabular}{|c|c|c|c|c|c|c|}
\hline \multirow{2}{*}{ Herbicide } & \multirow{2}{*}{ Rainfall (mm) } & \multicolumn{5}{|c|}{ Depth $(\mathrm{cm})$} \\
\hline & & 2.5 & 5.0 & 10.0 & 15.0 & 30.0 \\
\hline \multirow{2}{*}{ With } & 40 & $12.33 \mathrm{c}$ & $16.07 \mathrm{~b}$ & $17.55 \mathrm{~b}$ & $19.64 \mathrm{a}$ & $19.49 \mathrm{a}$ \\
\hline & 80 & $17.72 \mathrm{ab}$ & $16.64 \mathrm{~b}$ & $17.98 \mathrm{ab}$ & $19.21 \mathrm{a}$ & $18.41 \mathrm{ab}$ \\
\hline \multirow{2}{*}{ Without } & 40 & $17.63 \mathrm{a}$ & $17.17 \mathrm{a}$ & $18.67 \mathrm{a}$ & $18.24 \mathrm{a}$ & $18.60 \mathrm{a}$ \\
\hline & 80 & $21.20 \mathrm{a}$ & $21.20 \mathrm{a}$ & $20.23 \mathrm{a}$ & $20.25 \mathrm{a}$ & $21.06 \mathrm{a}$ \\
\hline
\end{tabular}

Means followed by the same letter on the line, do not differ by Tukey test at $5 \%$ probability.

was increased, smaller phytotoxicity grade were noted. These results indicate flumioxazin mobility is limited to depths near to $10 \mathrm{~cm}$ for rainfall lower than $80 \mathrm{~mm}$.

In general terms, it can be concluded that the low flumioxazin mobility along the Dystrophic Red Yellow Latosol profile does not provide residual effects on the substrate, which could to harm the subsequent crops. Similar results were observed by Alister et al. (2008) and Deuber et al. (2009).

\section{Discussion}

Despite the movement of herbicide molecules and their interaction in adsorption and desorption processes are not total know in Brazilian weather conditions and soils, processes such as sorption and desorption can influence the movement of the herbicide into the soil.

This study demonstrated that in both of the simulated amounts of rainfall $(40$ and $80 \mathrm{~mm}$ ), the dry matter of the plants was considerably reduced with the presence of flumioxazin. However, in $40 \mathrm{~mm}$ rainfall simulation, the dry matter decreased only in minors depth. That shows that leaching of the flumioxazin herbicide depends of the water amount.

The herbicide presence in the soil affected the plant development, including its heights. The reduction of the biomass production and plant height can be due to the reduction in the amount of photo-assimilated that were transported to the roots, affecting their normal development. The herbicide movement in soil layers and the consequent contamination provided a significant decrease of these variables.

It was noted that the amount of water from rain or irrigation favors the movement of flumioxazin herbicide through the layers of Dystrophic Red Yellow Latosol. Thus, the depth that flumioxazin herbicide can achieve depends of the amount of water in the soil, where more water means a greater depth, like observed in Oliveira et al. (1999) and Deuber et al. (2009).

The composition of clays and organic matter present in the Dystrophic Red Yellow Latosol may have been the most important factor that caused the flumioxazin sorption. That could prevent the flumioxazin to reach a greater depth for $40 \mathrm{~mm}$ rainfall simulation. It is known that, in general, there is an inverse relationship between the sorption and herbicide leaching potential (Vivian et al., 2007).

Moreover, the herbicidal sorption capacity of the soil is important because it is directly related to the availability of these particles to their herbicidal action, to microbial attack and biodegradation, being inversely proportional to the possibility of leaching and contamination at great depths (Andréa and Luchini, 2002).

In terms of adsorption capacity, it was high for the flumioxazin herbicide, providing a low movement of the herbicide through the soil layer. The effect of reducing the availability of flumioxazin may be related to phenomena of interaction between the sorptive soil complex cations and the rich centers electrons herbicide molecule and cation binders (eg, calcium and or magnesium) of exchange complex and clays (Lima et al., 1999) and / or soil organic matter and $\mathrm{pH}$ (Grey et al., 1997).

Notice that high ionic exchange capacity may also cause a positive correlation with the sorption capacity of other herbicides, like the sulfentrazone herbicide (Vivian et al., 2007). These results were also found by other authors in different soil types (Sprankle et al., 1975).

However the process of distribution and herbicide degradation in soil is dynamic and unique to each soilherbicide. It depends of the relation among chemical and physical properties of the herbicide, interaction with the soil and its half-life (t $1 / 2$ ), climate conditions, vegetation, soil 
properties and management area (Hager and Nordby, 2004; Vivian et al., 2007).

Materials and methods

\section{Local e material used}

Between August and October of 2018, a laboratory experiment was carried in Alta Floresta-MT, in the Southern Amazon, Brazil, geographical coordinates 9 $53^{\prime} 50^{\prime \prime} \mathrm{S}$ and $56^{\circ} 5^{\prime} 41^{\prime \prime} \mathrm{W}$ and $320 \mathrm{~m}$ of altitude. The studied variable was flumioxazin's effect on initial development of sorghum (Sorghum vulgare) for different rainfall simulated levels.

A PVC pipe, with paraffin in internal walls, was filled with substrate. Soil, classified as Order: Latosol, suborder: Red Yellow Latosol, Group: Distrophic Red Yellow Latosol, subgroup: Dystrophic Red Yellow Latosol (Embrapa, 2013) was the substrate, taken from the 0 to $0.20 \mathrm{~m}$ upper layer. The soil utilized had never been cultivated. Once soil samples were collected, they were dried indoors for 48 hours and subsequently sieved $(2 \mathrm{~mm})$. Substrate samples were submitted to chemical and physical analyses (Table 1). The analyses were conducted at Plante Certo Laboratory (Várzea Grande - MT, Brazil).

Preparation of experimental units and application of treatmentsPrimarily, PVC pipes $(0.50 \mathrm{~m}$ of length and $0.10 \mathrm{~m}$ of diameter) received a full central longitudinal cut. Following, the PVC pipes were re-assembled with duct tape as original shape. They were closed in one extreme by a permeable membrane. Later on, they were buried in vertical position into a sand box (membrane side facing down), supported by a wood structure. PVC pipes were then filled with substrate and water was added until the soil reached its field capacity. PVC pipes were kept for 24 hours in vertical position in order to allow drainage.

After this period, flumioxazin was applied in the PVC pipes $\left(50 \mathrm{~g}\right.$ i.a. ha $\left.{ }^{-1}\right)$. For the application process, a sprayer of $\mathrm{CO}_{2}$ (pressure of 3.00 bar, nozzle model SF 110.02) was used, calibrated to spray volume of $250 \mathrm{~L} \mathrm{ha}^{-1}$. At the time of application, air temperature was of $30{ }^{\circ} \mathrm{C}$, relative humidity $63.00 \%$, cloudiness $25.00 \%$ and negligible wind.

\section{Plant materials}

After a period of 24 hours, daily rainfall amount of $10 \mathrm{~mm}$ was simulated within the PVC pipes, until a total amount of 40 and $80 \mathrm{~mm}$ was reached. Then, immediately, PVC pipes were put into horizontal position and the duct tape was removed, resulting in two pieces of PVC pipes with substrate. For each piece, five sorghum seeds (Sorghum vulgare L., commercial variety BRS 655) were sown, with distances $0.025 ; 0.05 ; 0.10 ; 0.15$ and $0.30 \mathrm{~m}$ from the upper to lower sides.

\section{Variables analyzed}

Sorghum plants developed through 15 days, after which plant height, dry biomass weight and phytotoxicity were determined. Plant height was considered as the distance from the base until the last leave apex, and it was measured by using a ruler. Dry biomass weight determination was done after plants were cut from the base and dried for 96 hours in a forced air oven $\left(70{ }^{\circ} \mathrm{C}\right)$. Weight of dried samples was determined using a digital balance. For the phytotoxicity determination, grades from 1 (no phytotoxicity) up to 9 (death of the plant) were used, following method from Alam (1974).

\section{Statistical design}

A factorial experiment design, with 3 factors and 4 repetitions, was adopted. The factors were represented by herbicide (with and without application), rainfall (total of 40 and $80 \mathrm{~mm}$ ) and depth (0.025;0.05;0.10; 0.15 and $0.30 \mathrm{~m}$ ). Measure data was analyzed using ANOVA and Tukey's mean test (5.00 and $1.00 \%$ ). Regression analysis was performed in order to assess quantitative factors. We used the statistical program SISVAR (Ferreira, 2011).

\section{Conclusions}

According to the evaluations, and from the results obtained, it can be concluded that the herbicide fumioxazin has low mobility in a Dystrophic Red Yellow Latosol at Brazilian Southern Amazon. It can also be verified that this herbicide has high adsorptive capacity along the profile in Red Dystrophic Red Latosol. In addition, it does not cause residual effects on the substrate, ie its mobility is limited to the first $2.5 \mathrm{~cm}$ along the profile of this soil.

Thus, it is possible to infer that, despite having great soil contamination capacity, this herbicide, if used correctly, only moves in the superficial part of the Amazonian soil, which allows its conscious use and can be part of weeds management programs in this Biome.

References

Alam (1974) Asociación Latinoamericana de Malezas. Recomendaciones sobre unificación de los sistemas de evaluacion en ensayos de control de malezas. ALAM 1:3538.

Alister C, Rojas S, Gómez P, Kogan M (2008) Dissipation and movement of flumioxazin in soil of four field sites in Chile. Pest Manag Sci 64: 579-583.

Carbonari CA, Gomes GLGC, Velini ED (2010) Effects of nonrainy periods on the efficacy of flumioxazin applied to soil and sugarcane straw. R Bras Herb 9:81-88.

Deuber R, Pastre W, Giusto AB (2009) Leaching of flazasulfuron and flumioxazin in two different oxisols. $R$ Bras Herb 8:27-36.

Embrapa (2013) Brazilian system of soil classification. Embrapa. Brasília. 353 pp.

Fao (2012) FAO statistical yearbook. Food and Agriculture Organization (FAO) of the United Nations, Rome, Italy. Available at: http://www.fao.org/docrep/015/i2490e/i2490e00.htm. Accessed: 15 feb. 2016.

Fast BJ, Ferrell JA, Macdonald GE, Krutz JL, Kline WN (2010). Picloram and aminopyralid sorption to soil and clay minerals. Weed Sci 58:484-489.

Ferrell JA, Vencill WK, Xia K, Grey TL (2005) Sorption and desorption of flumioxazin to soil, clay minerals and ion exchange resin. Pest Manag Sci 61:40-46.

Haim K, Michael YG (2014) Reduced herbicide leaching by in situ adsorption of Herbicide-Micelle formulations to soils. $J$ Agric Food Chem 62:50-57.

Kerr GW, Stahlman PW, Dille JA (2004) Soil pH and cation exchange capacity effects sunflower tolerance to sulfentrazone. Weed Technol 18:243-247. 
Lima RO, Oliveira MF, Silva AA, Magalhães JV (1999) Behavior of the herbicide flumioxazin in soil with different doses of limestone. R Ceres 46:607-613.

López-Piñeiro A, Albarrán DP, Becerra AD, Sánchez-Llerena J (2013) Sorption, leaching and persistence of metribuzin in Mediterranean soils amended with olive mill waste of different degrees of organic matter maturity. J Environ Manag 122:76-84.

Mitchell C, Brodie J, White I (2005) Sediments, nutrients and pesticide residues in event flow conditions in streams of the Mackay Whitsunday region, Australia. Mar Pollut Bull 51:23-36

Mueller TC, Boswell BW, Mueller SS, Steckel LE (2014) Dissipation of fomesafen, saflufenacil, sulfentrazone, and flumioxazin from a Tennessee soil under field conditions. Weed Sci 62:664-671.

Nicholls PH (1988) Factors influencing entry of pesticides into soil water. Pest Sci 22:123-137.

Ohmes AG, Mueller TC (2007) Sulfentrazone adsorption and mobility in surface soil of the Southern United States. Weed Technol 21:796-800.

Oliveira MF, Silva AA, Ferreira FA, Ruiz HA (1999) Lixiviation of flumioxazin and metribuzin in two soils under laboratory conditions. Planta Daninha 17:207-215.

Papiernik SK, Koskinen WC, Barber BL (2012) Low sorption and fast dissipation of the herbicide saflufenacil in surface soils and subsoils of an eroded prairie landscape. J Agric Food Chem 60:10936-10941.

PPDB (2017). Pesticide Properties Database. Agriculture \& Environment Research Unit. University of Hertfordshire. Available at: http://sitem.herts.ac.uk/aeru/ppdb/en/index.htm. Accessed: 15 dec. 2017

Prado ABCA, Obara FEB, Brunharo CAG, Melo MSC, Christoffoleti PJ, Alves MC (2013) Dinâmica de herbicidas aplicados em pré-emergência sobre palha de cana-deaçúcar em diferentes regimes hídricos. $\mathrm{R}$ Bras Herb 12:179-187.

Rodrigues BN, Almeida FS (2011) Guide of herbicides. lapar. Londrina. 697p.
Rozemeijer JC, Broers HP (2007) The groundwater contribution to surface water contamination in a region with intensive agricultural land use (Noord-Brabant, The Netherlands). Environ Pollut 148(3):695-706.

Rostampour MF, Yarnia M, Khoee FR, Seghatoleslami MJ, Moosavi GR (2013) Physiological response of forage sorghum to polymer under water deficit conditions. Agron J 105:951-959.

Sanders GJ, Arnoldt SK (2012) Osmotic adjustment under drought conditions. In: Aroca R (ed) Plant responses to drought stress. From morphological to molecular features. Springer. Berlin. pp:199-229.

Smith SR, Keene T (2012) Switchgrass biomass yield and quality with multiple fertilizer applications and harvest dates. Abstract 257-35. In: Visions for a sustainable planet, ASA, CSSA and SSSA Annual Meetings, Cincinnati. Ohio. p:21-24.

Tanabe A, Mitobe H, Kawata K, Yasuhara A, Shibamoto T (2001) Season and spatial studies on pesticides residues in surface waters of the Shinano river in Japan. J Agric Food Chem 49:3847-3852.

Troiano J, Weaver D, Marade J, Spurlock F, Pepple M, Nordmark C (2001) Summary of well water sampling in California to detect pesticide residues resulting from nonpoint-source applications. J Environ Qual. 30(2):448459.

Umiljendić JG, Radivojević L, Đorđević T, JovanovićRadovanov K, Šantrić L, Đurović-Pejčev R, Elezović I. (2013) A bioassay technique to study clomazone residues in sandy loam soil. Pestic Phytom 28:203-211.

Vivian $R$, Reis $M R$, Jakelaitis $A$, Silva $A F$, Guimarães $A A$, Santos JBV, Silva AA (2006) Persistence of sulfentrazone in red-yellow argisol cultivated with sugar cane. Planta Daninha 24:741-750.

Wssa (2002) Weed Science Socitey of America. Herbicide Handbook. Champaign pp.200-202.

Yamashita OM, Carvalho RV, Carvalho MAC,Tieppo RC, Dallacort R (2018) Mobility of flumioxazin in argisol at Southern Amazon. Tchê Quim 15:473-479. 